\title{
Intellectual History as History of Engagement? The French Scholarship - CORRIGENDUM
}

\author{
Massimo Asta
}

(Received 18 November 2021; revised 18 November 2021; accepted 18 November 2021)

doi:10.1017/S1479244321000184, Published online by Cambridge University Press, 14 April 2021.

This review essay published online with a missing acknowledgement which is included below:-

The author would like to acknowledge that this project has received funding from the European Union's Horizon 2020 research and innovation programme under the Marie Sklodowska-Curie grant agreement no. 837524.

\section{Reference}

Massimo Asta, "Intellectual History as History of Engagement? The French Scholarship", Modern Intellectual History, Published online 14 April 2021, doi:10.1017/S1479244321000184

Cite this article: Asta M (2022). Intellectual History as History of Engagement? The French Scholarship CORRIGENDUM. Modern Intellectual History 19, 660-660. https://doi.org/10.1017/S1479244321000664

(C) The Author(s), 2022. Published by Cambridge University Press. This is an Open Access article, distributed under the terms of the Creative Commons Attribution licence (http://creativecommons.org/licenses/by/4.0/), which permits unrestricted re-use, distribution, and reproduction in any medium, provided the original work is properly cited. 